ISSN: 2302-8556

E-Jurnal Akuntansi Universitas Udayana

Vol.25.2.November (2018): 1015-1040

DOI: https://doi.org/10.24843/EJA.2018.v25.i02.p08

\title{
Pengaruh Independensi, Kompetensi, Integritas, dan Struktur Audit Terhadap Kualitas Audit Kantor Inspektorat
}

\author{
A A Ngr Agung Wira Gita ${ }^{1}$ \\ A. A. N. B. Dwirandra ${ }^{2}$ \\ ${ }^{1}$ Fakultas Ekonomi dan Bisnis Universitas Udayana (Unud), Bali, Indonesia \\ email: wiragita09@gmail.com/Telp: +6281338197410 \\ ${ }^{2}$ Fakultas Ekonomi dan Bisnis Universitas Udayana (Unud), Bali, Indonesia
}

\begin{abstract}
ABSTRAK
Inspektorat dalam melaksanakan profesinya harus memperhatikan kualitas auditnya. Untuk menghasilkan kualitas audit yang baik, seorang auditor harus memperhatikan faktor-faktor yang memengaruhi kualitas audit. Independensi, Kompetensi, Integritas, dan Struktur Audit merupakan faktor-faktor yang memengaruhi kualitas audit. Tujuan penelitian ini adalah untuk mengetahui secara empiris pengaruh Independensi, Kompetensi, Integritas dan Struktur Audit terhadap Kualitas Audit. Penelitian ini dilakukan di 4 Kantor Inspektorat Kabupaten/Kota di Provinsi Bali. Jumlah sampel yang diambil sebanyak 60 auditor, Metode pengumpulan data yang digunakan dalam penelitian ini adalah metode survei dengan teknik kuesioner. Teknik analisis data yang digunakan adalah Analisis Regresi Linear Berganda. Berdasarkan hasil analisis ditemukan bahwa Independensi, Kompetensi, Integritas, dan Struktur Audit berpengaruh positif signifikan terhadap kualitas audit. Hal ini menunjukkan bahwa seorang auditor harus tetap independen, berkompeten, berani mengambil resiko, bertanggungjawab, dan memiliki pengetahuan tentang prosedur audit yang baik.
\end{abstract}

Kata kunci: independensi, kompetensi, integritas, struktur audit, dan kualitas audit

\begin{abstract}
Inspectorate in carrying out its profession must pay attention to the quality of its audit. To produce good audit quality, an auditor should consider the factors that affect audit quality. Independence, Competence, Integrity, and Audit Structure are the factors that affect audit quality. The purpose of this study is to know empirically the influence of Independence, Competence, Integrity and Audit Structure of Audit Quality. The research was conducted in 4 District / City Inspectorate Offices in Bali Province. The number of samples taken as many as 60 auditors, Data collection methods used in this study is a survey method with questionnaire techniques. Data analysis technique used is Multiple Linear Regression Analysis. Based on the analysis results found that Independence, Competence, Integrity, and Audit Structure have a significant positive effect on audit quality. This suggests that an auditor must remain independent, competent, risk-taking, responsible, and knowledgeable about sound auditing procedures.

Keywords: independence, competence, integrity, audit structure, and audit quality
\end{abstract}


A.A Ngurah Agung Wira Gita dan A.A. N. B. Dwirandra. Pengaruh...

\section{PENDAHULUAN}

Tuntutan pelaksanaan akuntabilitas sektor publik terhadap terwujudnya good governance di Indonesia semakin meningkat. Tuntutan ini wajar, karena beberapa penelitian menunjukkan bahwa terjadinya krisis ekonomi di Indonesia ternyata disebabkan oleh buruknya pengelolaan (bad governance) dan buruknya birokrasi (Sunarsip, 2001).

Berdasarkan apa yang disampaikan oleh Mardiasmo (2005), terdapat tiga aspek utama yang mendukung terciptanya kepemerintahan yang baik (good governance), yaitu pengawasan, pengendalian, dan pemeriksaan. Pengawasan merupakan kegiatan yang dilakukan oleh pihak di luar eksekutif, yaitu masyarakat dan Dewan Perwakilan Rakyat Daerah (DPRD) untuk mengawasi kinerja pemerintahan. Pengendalian (control) adalah mekanisme yang dilakukan oleh eksekutif untuk menjamin bahwa sistem dan kebijakan manajemen dilaksanakan dengan baik sehingga tujuan organisasi dapat tercapai. Sedangkan pemeriksaan (audit) merupakan kegiatan yang dilakukan oleh pihak yang memiliki independensi dan memiliki kompetensi profesional untuk memeriksa apakah hasil kinerja pemerintah telah sesuai dengan standar yang ditetapkan. Terkait dengan proses pengawasan dan pemeriksaan atas pengelolaan keuangan daerah, oleh Inspektorat wilayah Provinsi (Itwilprop), Inspektorat Wilayah Kabupaten/kota (Itwilkab/Itwilkot), sebagai unsur pengawas penyelenggaraan pemerintah daerah yang bertanggungjawab langsung kedapa gubernur, bupati/walikota dan secara teknis administratif mendapat pembinaan dari sekretaris daerah. 
Guna mewujudkan good governance di lingkungan pemerintahan daerah, pemerintah harus melakukan reformasi dalam segala aspek pengelolaan keuangan daerah. Salah satu langkah yang harus dilakukan pemerintah daerah adalah melakukan reformasi audit baik internal maupun eksternal dalam penyelenggaraan pemerintahan. Melalui reformasi audit ini diharapkan kegiatan audit di lingkungan instansi pemerintah dapat berjalan lebih maksimal, sehingga dapat mengurangi terjadinya kesalahan prosedur dan tindak pidana yang sering dilakukan auditee, yang berdampak pada kerugian negara.

Dengan adanya reformasi dalam bidang pengawasan maka kualitas pengawasan yang dilakukan inspektorat daerah akan semakin baik, sehingga akan meningkatkan kualitas hasil pemeriksaan/inspektorat dalam pengawasan pengelolaan keuangan daerah. Disampaikan oleh Pusdiklat Pengembangan SDM (2011:41) bahwa, audit atas pelaksanaan pengelolaan keuangan daerah dapat dilakukan oleh pengawas eksternal, dan pengawas internal. Pengawas eksternal terdiri dari pengawasan oleh DPR, BPK, dan masyarakat. Sedangkan, pengawas internal terdiri dari BPKP, inspektorat, dan pengawasan atasan langsung.

Pengawasan dapat dilaksanakan oleh pengawas internal yaitu inspektorat, dengan adanya keberadaan inspektorat diharapkan mampu mencegah kasus penyimpangan. Pengawasan berfungsi membantu agar tujuan yang ditetapkan organisasi dapat tercapai, di samping itu pengawasan berfungsi mendeteksi secara dini terjadinya penyimpangan pelaksanaan, penyalahgunaan wewenang, pemborosan dan kebocoran (Sukriah, dkk 2009). Kualitas hasil pemeriksaan merupakan indikator penilaian terhadap pengawasan yang telah dilakukan oleh 
aparat pemeriksa. Hasil pemeriksaan yang mempunyai kualitas baik diharapkan mampu memberikan jaminan terhadap tata kelola pemerintahan yang transparansi dan bertanggung jawab (Rai, 2008). Fungsi pengawasan diwujudkan dalam bentuk kualitas hasil pemeriksaan yang dilakukan oleh aparat pemeriksa untuk memberikan rekomendasi sebagai bahan perbaikan akuntabitas untuk dapat ditindak lanjuti. Inspektorat daerah mempunyai tugas menyelenggarakan kegiatan pengawasan umum pemerintah daerah dan tugas lain yang diberikan kepala daerah, sehingga dalam tugasnya inspektorat sama dengan auditor internal (Falah, 2005).

Masalah kasus korupsi yang ada di daerah menyita perhatian publik, bahkan berimplikasi pada penyidikan oleh penegak hukum sebagaimana sering didengar tentang kasus-kasus APBD yang terjadi di Bali yang mencuat melalui media cetak. Dari sembilan Kabupaten yang ada di Provinsi Bali, beberapa kabupaten pernah menjadi sorotan masyarakat dan media tentang terjadinya kasus korupsi yang menjerat aparat pemerintahnya, bahkan sampai ke ranah hukum. Salah satu pemerintah daerah di Bali yang menjadi perhatian publik saat ini adalah Kabupaten Karangasem. Berkaitan dengan itu kasus korupsi proyek pekerjaan pengembangan sistem distribusi air minum di 4 (empat) kecamatan ini sudah berlangsung dari tahun 2009-2010. Kasus ini yang juga melibatkan salah seorang mantan pejabat pemerintah yaitu mantan Kepala Dinas Pekerjaan Umum Karangasem, I Nyoman Arnawa yang kini dijatuhakn vonis 1,5 tahun penjara (http://bali.tribunnews.com, 23 desember 2016). Hal tersebut disinyalir 
disebabkan kurang maksimalnya pengawasan dan kualitas pemeriksaan internal pemerintah kabupaten yang dilakukan oleh Inspektorat Kabupaten Karangasem.

Beberapa temuan oleh BPK juga terjadi di kabupaten/kota ini yang berdasarkan atas siaran pers BPK Perwakilan Provinsi Bali pada Jumat, 2 Juni 2017 mengatakan bahwa LHP (Laporan Hasil Pemeriksaan) di 9 kabupaten/kota di Bali adalah WTP (Wajar Tanpa Pengecualian). Tetapi masih terdapat kelemahan dan ketidakpatuhan terhadap ketentuan peraturan perundangundangan, seperti halnya di Kota Denpasar yaitu hasil pelaksanaan PTSP (Pelayanan Terpadu Satu Pintu) yang menunjukan jumlah perizinan terbit belum mencapai target dan peningkatan nilai investasi tidak diringi dengan peningkatan jumlah usaha baru terdapat izin kadaluwarsa yang belum diperpanjang selama TA 2016 sampai Triwulan 2017 2. Di Kabupaten Tabanan juga ada indikasi temuan oleh BPK yang menyebutkan lemahnya dan kurang terdistribusinya obat-obatan di beberapa rumah sakit di Kabupaten Tabanan dan sertifikasi tenaga pendidik yang masih belum memadai (http://kabarnusa.com, 19 Desember 2017). Kabupaten Badung juga mengalami LHP yang menjadi suatu temuan dalam hal hasil pendapatan daerah yang tidak tepat dan dinyatakan karena adanya kesalahan pada administrasi (http://denpostnews.com). Dan di Kabupaten Gianyar di dapati temuan oleh BPK yaitu dalam hal pengelolaan dana desa yang sampai saat ini belum jelas datanya yang dipertegas dengan tidak keakuratan data, penggunaan yang tidak sesuai prioritas, bukti SPJ yang tidak memadai dan pembayaran tidak sesuai fisik pekerjaan. BPK juga menyatakan pengadaan tidak sesuai ketentuan dan penatausahaannya yang tidak tertib (http://cendananews.com, 14 April 2018). 
Dalam hal ini dari beberapa temuan oleh BPK di beberapa instansi pemerintah daerah, maka dipertanyakan kembali kualitas audit oleh inspektorat daerah. Untuk itu faktor independensi, kompetensi yang memadai, integritas yang baik, serta pemahaman yang baik dalam pendekatan struktur audit dirasa harus dimiliki oleh inspektorat daerah.

Bentuk pemeriksaan internal auditor memiliki review yang baik, dan didukung oleh independensi, kompetensi, dan integritas sehingga tidak akan bermunculan berbagai bentuk temuan oleh eksternal auditor dalam pelaksanaan pemerintahan sampai saat ini.

Kualitas pemeriksaan yang baik dapat dicapai apabila seorang pemeriksa memiliki kompetensi dan independensi yang cukup baik pula. Fenomena kualitas pemeriksaan tidak serta merta hanya dipengaruhi oleh faktor di atas, namun tergantung juga dengan adanya faktor kontinjensi, satu diantaranya adalah etika pemeriksa dapat memberikan dampak pencapaian tingkat kualitas pemeriksaan yang telah dilakukan. Indikasi rendahnya kualitas pemeriksaan yang dilakukan oleh Inspektorat Kabupaten Badung, Kabupaten Tabanan, dan Kabupaten Gianyar kemungkinan sangat dipengaruhi oleh faktor-faktor tersebut dalam menunjang fungsi pengawasan daerah.

Faktor pertama yang mungkin mempengaruhi kualitas audit adalah Independensi. Mulyadi (2002:9) mendefinisikan independensi sebagai keadaan bebas dari pengaruh, tidak dikendalikan oleh pihak lain, tidak tergantung pada orang lain dan akuntan publik yang independen haruslah akuntan publik yang tidak terpengaruh dan tidak dipengaruhi oleh berbagai kekuatan yang berasal dari 
luar diri akuntan dalam mempertimbangkan fakta yang dijumpainya dalam pemeriksaan.

Seorang auditor dalam melaksanakan tugas audit harus didukung dengan sikap independen, dimana seorang auditor tidak boleh dipengaruhi oleh pihak lain, dan tidak dikendalikan oleh pihak lain. Maka dari itu semakin tinggi tingkat independensi seorang auditor akan semakin tinggi pula kualitas audit yang dihasilkan. Dalam hubungannya dengan auditor, independensi berpengaruh penting sebagai dasar utama agar auditor dipercaya oleh masyarakat umum. Alim, dkk (2007) menemukan bahwa independensi berpengaruh signifikan terhadap kualitas audit. Angge Septiari (2013) dan L. Purwanti (2007) mengemukakan bahwa independensi berpengaruh signifikan terhadap kualitas audit. Berdasarkan penjelasan tersebut maka hipotesis yang dibangun adalah:

$\mathrm{H}_{1}$ : Independensi auditor berpengaruh positif signifikan terhadap kualitas audit.

Faktor kedua yang diduga mempengaruhi kualitas audit adalah kompetensi. Auditor membutuhkan sebuah kompetensi. Kompetensi diperoleh melalui pendidikan dan pengalaman. Anggota seyogyanya tidak menggambarkan dirinya memiliki keandalan atau pengalaman yang tidak mereka miliki (Mulyadi, 2002:58). Kompetensi adalah kualifikasi yang dibutuhkan oleh auditor untuk melaksanakan audit dengan benar (Rai, 2008). Secara konseptual kompetensi yang tinggi dimiliki pemeriksa akan memberikan kualitas hasil pemeriksaan baik. Salah satu hal yang menyebabkan kompetensi aparat pemeriksa kurang maksimal adalah kurangnya tingkat pendidikan dan pelatihan ketrampilan auditor aparat 
A.A Ngurah Agung Wira Gita dan A.A. N. B. Dwirandra. Pengaruh...

pemeriksa melalui sertifikasi Jabatan Fungsional Auditor (JFA) yang dilaksanakan dan difasilitasi oleh Pusdiklat BPKP.

Menurut Tubbs (1992) dalam Mabruri dan Winarna (2010) menyatakan bahwa dalam mendeteksi sebuah kesalahan, seorang auditor harus didukung dengan pengetahuan tentang apa dan bagaimana kesalahan tersebut terjadi. Hasil penelitian Alim, dkk (2007) menyatakan bahwa kompetensi berpengaruh signifikan terhadap kualitas hasil pemeriksaan, hasil penelitian T. Hapsari, dan L. Purwanti (2007), Achmad Badjuri (2012) dan Muh. Taufiq Efendy (2010) yang menyatakan bahwa kompetensi berpengaruh signifikan terhadap kualitas audit. Berdasarkan penjelasan di atas maka hipotesis yang dibangun adalah:

$\mathrm{H}_{2}$ : Kompetensi auditor berpengaruh positif signifikan terhadap kualitas audit.

Faktor ketiga yaitu integritas auditor dimana integritas juga berpengaruh terhadap kualitas hasil audit. Sunarto (2003) dalam Sukriah, dkk (2009) menyatakan bahwa integritas dapat menerima kesalahan yang tidak disengaja dan perbedaan pendapat yang jujur, tetapi tidak dapat menerima kecurangan prinsip. Dengan integritas yang tinggi, maka auditor dapat meningkatkan kualitas hasil auditnya (Pusdiklatwas BPKP, 2005). Integritas mengharuskan seorang anggota untuk antara lain, bersikap jujur dan berterus terang tanpa harus mengorbankan rahasia penerima jasa, pelayanan dan kepercayaan publik tidak boleh dikalahkan oleh keuntungan pribadi (Mulyadi, 2002:57).

Integritas merupakan kualitas yang mendasari kepercayaan publik dan merupakan patokan bagi anggota dalam menguji semua keputusannya. Penelitian oleh Carolita (2011), Rahardjo (2011) dan Arianti (2014) yang menunjukkan 
bahwa integritas auditor berpengaruh signifikan terhadap kualitas hasil pemeriksaan. Pernyataan sebelumnya sejalan dengan yang diungkapkan Mulyadi (2002:56) yang menyatakan bahwa integritas adalah suatu elemen karakter yang mendasari timbulnya pengakuan professional. Berdasarkan pernyataan tersebut dengan hipotesis yang dibangun adalah:

$\mathrm{H}_{3}$ : Integritas auditor berpengaruh positif signifikan terhadap kualitas audit.

Selain beberapa faktor diatas, struktur audit juga memiliki fungsi meliputi petunjuk mengenai apa yang harus dilakukan dan instruksi bagaimana hal tersebut harus diselesaikan, alat-alat untuk melakukan koordinasi, pengawasan, pengendalian audit, dan alat-alat untuk penilaian kualitas kerja yang dilaksanakan. Penelitian Bamber et al., (1989) menyatakan bahwa kantor akuntan publik yang menggunakan struktur audit akan meningkatkan kinerja auditor dan sebaliknya kantor akuntan publik yang menggunakan struktur audit memiliki potensi meningkatnya konflik peran dan ketidakjelasan peran yang dirasakan oleh staf auditnya. Dengan adanya prosedur audit yang sistematis dan rinci membantu auditor dalam melaksanakan audit sehingga struktur audit terbukti membantu auditor dalam meningkatkan kualitas audit.

Dalam meningkatkan kualitas dan efisiensi audit, kantor akuntan publik mulai menggunakan struktur audit dalam pelaksanaan auditnya sehingga decisionmaker akan lebih memfokuskan pada informasi yang relevan dengan masalah audit (Bamber, et al. 1989). Pendekatan struktur audit juga berhubungan dengan total waktu pelaksanaan audit yang lebih lama, di mana menggunakan lebih banyak sumber daya dan input. Namun ketika ada kejadian yang tidak 
terantisipasi, maka perusahaan yang menggunakan pendekatan struktur audit lebih mampu beradaptasi secara cepat sehingga waktu yang digunakan untuk melakukan penelitian menjadi lebih singkat (Bamber dan Snowball, 1988).

Setiap staf audit harus memiliki pengetahuan tentang struktur audit yang baku karena tanpa pengetahuan tersebut staf audit cenderung mengalami kesulitan dalam menjalankan tugasnya. Hal ini mempengaruhi koordinasi sehingga dapat mengganggu kinerja auditor. Hasil penelitian Fanani (2008) dan Eriani (2010) menunjukkan bahwa Kantor Akuntan Publik yang menggunakan struktur audit meningkatkan kinerja auditor. Berdasarkan pendekatan teori penjelasan diatas dapat dirumuskan hipotesis sebagai berikut. Berdasarkan penjelasan di atas maka hipotesis yang dibangun adalah:

$\mathrm{H}_{4}$ : Struktur audit berpengaruh positif signifikan terhadap kualitas audit.

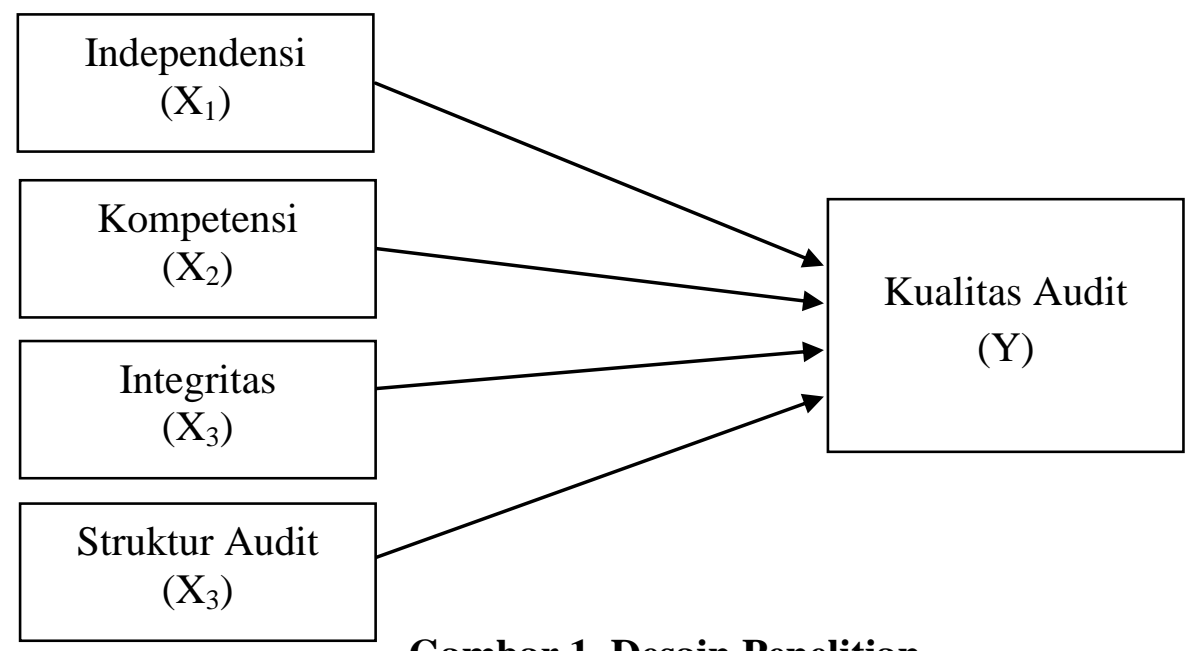

Gambar 1. Desain Penelitian

\section{METODE PENELITIAN}

Penelitian ini merupakan penelitian kuantitatif yang berbentuk asosiatif, yakni penelitian yang meneliti pengaruh suatu variabel terhadap variabel lainnya atau mengetahui hubungan antar variabel (Sugiyono, 2013). Penelitian ini membahas 
mengenai pengaruh independensi, kompetensi, integritas, dan struktur audit terhadap kualitas audit inspektorat.

Lokasi penelitian dilakukan pada Inspektorat Kabupaten Badung, Kota Denpasar, Kabupaten Gianyar, dan Kabupaten Tabanan. Sedangkan obyek dalam penelitian adalah pengaruh independensi, integritas, kompetensi, struktur audit, dan kualitas audit pemerintah.

Variabel terikat dalam penelitian ini adalah kualitas hasil audit (Y) yang diukur dengan menggunakan dua indikator yaitu kesesuaian pemeriksaan dengan standar audit, dan kualitas hasil laporan pemeriksaan. Variabel bebas dalam penelitian ini adalah independensi, kompetensi, integritas, dan struktur audit yang masing-masing diukur dengan menggunakan indikator. Independensi (X1) yang diukur dengan menggunakan tiga indikator yaitu independensi penyusunan anggaran, independensi pelaksanaan pekerjaan pemeriksaan, dan independensi pelaporan. Kompetensi (X2) yang diukur dengan menggunakan tiga indikator yaitu mutu personal, pengetahuan umum, dan keahlian khusus. Integritas (X3) yang diukur dengan menggunakan empat indikator yaitu kejujuran auditor, keberanian auditor, sikap bijaksana auditor, dan tanggung jawab auditor. Struktur Audit (X4) yang diukur dengan menggunakan satu indikator yaitu prosedural.

Jenis data yang digunakan dalam penelitian ini adalah data kuantitatif yang diperoleh dari skor dari jawaban responden terhadap kuesioner yang terkumpul. Sedangkan sumber data yang digunakan dalam penelitian ini adalah sumber primer berupa jawaban responden terhadap pertanyaan yang terdapat pada 
A.A Ngurah Agung Wira Gita dan A.A. N. B. Dwirandra. Pengaruh...

kuesioner mengenai independensi, kompetensi, integritas, struktur audit, dan kualitas audit.

Populasi dalam penelitian ini adalah auditor yang bekerja pada Inspektorat kabupaten/kota di Provinsi Bali meliputi Kabupaten Badung, Kota Denpasar, Kabupaten Gianyar, dan Kabupaten Tabanan. Pemilihan populasi di empat (4) populasi itu karena merupakan daerah dimana banyak terdapat auditor yang kompeten dan ahli di bidangnya yang tersebar dibeberapa kabupaten/kota di Provisi Bali. Sampel dalam penelitian ini adalah staf/pejabat pemeriksa dan auditor yang bekerja di Inspektorat Kota Denpasar, Kabupaten Badung, kabupaten Gianyar, dan Kabupaten Tabanan. Teknik pengambilan sampel dilakukan dengan pendekatan purposive sampling untuk menentukan sampel dari populasi yang memenuhi kriteria sesuai dengan yang penulis kehendaki, yaitu yang sudah mengikuti pendidikan dan pelatihan (diklat) sebagai auditor. Sampel yang disebar dalam penelitian ini sebanyak 120 kuesioner di empat Inspektorat dan masingmasing Inspektorat diberikan 20 eksemplar kuesioner.

Metode pengumpulan data yang digunakan dalam penelitian ini adalah menggunakan metode survey (survey method), yaitu menyebarkan daftar pertanyaan (kuesioner) yang akan diisi atau dijawab oleh responden auditor dan staf/pejabat pemeriksa pada Inspektorat di Kabupaten Badung, Kota Denpasar, Kabupaten Gianyar, dan Kabupaten Tabanan. Masing-masing Inspektorat diberikan 20 kuesioner dengan jangka waktu pengembalian 2 minggu terhitung sejak kuesioner diterima oleh responden. 
Teknik analisis data yang digunakan dalam penelitian ini adalah teknik analisis regresi linier berganda Sebelum melakukan pengujian regresi, terdapat beberapa asumsi yang harus dipenuhi agar data yang akan dimasukkan dalam model regresi telah memenuhi ketentuan dan syarat dalam regresi. Uji asumsi klasik dalam penelitian ini mencakup uji normalitas, multikolinearitas, dan heteroskedastisitas. Model regresi linier berganda dirumuskan sebagai berikut.

$Y=a+b_{1} X_{1}+b_{2} X_{2}+b_{3} X_{3}+b_{4} X_{4}+e$

Keterangan:

$\mathrm{Y}=$ Kualitas audit inspektorat

$\mathrm{a}=$ Nilai intersep (konstan)

$\mathrm{b}=$ Koefisien arah regresi

$\mathrm{X} 1=$ Independensi

$\mathrm{X} 2=$ Kompetensi

$\mathrm{X} 3=$ Integritas

X4 = Struktur Audit

$\mathrm{e}=$ Standar error

\section{HASIL DAN PEMBAHASAN}

Karakteristik responden dalam penelitian ini merupakan profil dari 60 responden yang berpartisipasi dalam pengisian kuesioner. Karakteristik responden dibagi menjadi beberapa kelompok menurut pendidikan terakhir, jabatan, umur, dan pengalaman audit pada Inspektorat Daerah.

Tabel 1.

Karakteristik Responden

\begin{tabular}{ccccc}
\hline No & Variabel & Klasifikasi & $\begin{array}{c}\text { Jumlah } \\
\text { (orang) }\end{array}$ & $\begin{array}{c}\text { Persentase } \\
(\boldsymbol{\%})\end{array}$ \\
\hline \multirow{2}{*}{1} & Pendidikan & D3 & 3 & 5,00 \\
& Terakhir & S1 & 48 & 80,00 \\
& & S2 & 8 & 13,33
\end{tabular}




\begin{tabular}{|c|c|c|c|c|}
\hline & & \multirow{2}{*}{$\begin{array}{ll}\text { Jumlah } & \text { S3 }\end{array}$} & 1 & 1,67 \\
\hline \multirow{5}{*}{2} & \multirow{4}{*}{ Jabatan } & & 60 & 100 \\
\hline & & Auditor Muda & 12 & 20,00 \\
\hline & & Auditor Pertama & 37 & 61,70 \\
\hline & & P2UPD & 11 & 18,30 \\
\hline & \multirow{5}{*}{ Umur } & Jumlah & 60 & 100 \\
\hline \multirow{4}{*}{3} & & $<30$ Tahun & 13 & 21,67 \\
\hline & & 30-45 Tahun & 42 & 70,00 \\
\hline & & 45 Tahun > & 5 & 8,33 \\
\hline & & Jumlah & 60 & 100 \\
\hline \multirow{5}{*}{4} & \multirow{4}{*}{$\begin{array}{l}\text { Pengalaman } \\
\text { Audit }\end{array}$} & 1-3 Tahun & 32 & 53,33 \\
\hline & & 4-6 Tahun & 21 & 35,00 \\
\hline & & 7-9 Tahun & 1 & 1,67 \\
\hline & & $>10$ Tahun & 6 & 10,00 \\
\hline & & Jumlah & 60 & 100 \\
\hline
\end{tabular}

Sumber: Data diolah, 2018

Berdasarkan Tabel 1. menunjukkan bahwa responden dalam penelitian ini sebagian besar memiliki pendidikan terakhir S1 sebanyak 48 orang (80\%). Berdasarkan jabatan menunjukkan bahwa responden dalam penelitian ini sebagian besar memiliki jabatan sebagai auditor muda sebanyak 12 orang (20\%). Berdasarkan umur menunjukkan bahwa responden dalam penelitian ini sebagian besar berumur $<30$ tahun yaitu sebanyak 13 orang $(21,67 \%)$. Berdasarkan pengalaman audit menunjukkan bahwa responden dalam penelitian ini sebagian besar memiliki pengalaman audit lapangan 1-3 tahun sebanyak 32 orang $(53,33 \%)$.

Suatu instrumen yang valid ditunjukkan dengan r Pearson Correlation $\geq$ 0,30 .

Tabel 2. Uji Validitas

\begin{tabular}{|c|c|c|c|c|}
\hline No. & Variabel & $\begin{array}{c}\text { Kode } \\
\text { Instrumen }\end{array}$ & $\begin{array}{c}\text { Pearson } \\
\text { Correlations }\end{array}$ & Keterangan \\
\hline 1 & Independensi (X1) & $\begin{array}{l}\text { X1.1 } \\
\text { X1.2 } \\
\text { X1.3 } \\
\text { X1.4 } \\
\text { X1.5 } \\
\text { X1.6 } \\
\text { X1.7 }\end{array}$ & & $\begin{array}{l}\text { Valid } \\
\text { Valid } \\
\text { Valid } \\
\text { Valid } \\
\text { Valid } \\
\text { Valid } \\
\text { Valid }\end{array}$ \\
\hline
\end{tabular}




\begin{tabular}{|c|c|c|c|}
\hline & & $\begin{array}{l}\text { X1.8 } \\
\text { X1.9 }\end{array}$ & $\begin{array}{l}\text { Valid } \\
\text { Valid }\end{array}$ \\
\hline \multirow[t]{10}{*}{2} & Kompetensi (X2) & $\mathrm{X} 2.1$ & Valid \\
\hline & & $\mathrm{X} 2.2$ & Valid \\
\hline & & $\mathrm{X} 2.3$ & Valid \\
\hline & & X2.4 & Valid \\
\hline & & $\mathrm{X} 2.5$ & Valid \\
\hline & & X2.6 & Valid \\
\hline & & $\mathrm{X} 2.7$ & Valid \\
\hline & & $\mathrm{X} 2.8$ & Valid \\
\hline & & X2.9 & Valid \\
\hline & & $\mathrm{X} 2.10$ & Valid \\
\hline \multirow[t]{14}{*}{3} & Integritas (X3) & X3.1 & Valid \\
\hline & & $\mathrm{X} 3.2$ & Valid \\
\hline & & X3.3 & Valid \\
\hline & & X3.4 & Valid \\
\hline & & X3.5 & Valid \\
\hline & & X3.6 & Valid \\
\hline & & X3.7 & Valid \\
\hline & & X3.8 & Valid \\
\hline & & X3.9 & Valid \\
\hline & & $\mathrm{X} 3.10$ & Valid \\
\hline & & X3.11 & Valid \\
\hline & & X3.12 & Valid \\
\hline & & X3.13 & Valid \\
\hline & & $\mathrm{X} 3.14$ & Valid \\
\hline \multirow[t]{2}{*}{$\overline{4}$} & Struktur Audit (X4) & $\mathrm{X} 4.1$ & Valid \\
\hline & & $\mathrm{X} 4.2$ & Valid \\
\hline \multirow[t]{10}{*}{$\overline{5}$} & Kualitas Audit (Y) & Y1 & Valid \\
\hline & & Y2 & Valid \\
\hline & & Y3 & Valid \\
\hline & & Y4 & Valid \\
\hline & & Y5 & Valid \\
\hline & & Y6 & Valid \\
\hline & & Y7 & Valid \\
\hline & & Y8 & Valid \\
\hline & & Y9 & Valid \\
\hline & & Y10 & Valid \\
\hline
\end{tabular}

Sumber: Data diolah, 2018

Uji reliabilitas mampu menunjukan sejauh mana instrument dapat dipercaya dan diharapkan. Nilai suatu instrument dikatakan reliable apabila nilai Alpha Cronbach $\geq 0,70$. Hasil uji reliabilitas dapat dilihat pada Tabel 3 . 
Tabel 3.

Hasil Uji Realibilitas

\begin{tabular}{lcc}
\hline \multicolumn{1}{c}{ Variabel } & Cronbach's Alpha & Keterangan \\
\hline Independensi (X1) & 0,882 & Reliabel \\
Kompetensi (X2) & 0,872 & Reliabel \\
Integritas (X3) & 0,951 & Reliabel \\
Struktur Audit (X4) & 0,663 & Reliabel \\
Kualitas Audit (Y) & 0,925 & Reliabel \\
\hline
\end{tabular}

Sumber: Data diolah, 2018

Berdasarkan Tabel 3. menunjukkan bahwa nilai Cronbach's Alpha masingmasing variabel lebih besar dari 0,70 yang artinya bahwa seluruh pernyataan dalam kuesioner penelitian ini reliabel dan dapat digunakan.

Uji normalitas menggunakan uji Kolmogorov-Smirnov, dengan uji ini dapat diketahui data yang digunakan berdistribusi normal atau tidak. Apabila Sign t hitung $>0.05$, maka data tersebut berdistribusi normal dan begitu juga sebaliknya (Santoso, 2001).

Tabel 4.

Hasil Uji Normalitas

\begin{tabular}{cccc}
\hline Variabel & $\begin{array}{c}\text { Kolmogrov- } \\
\text { Smirnov } Z\end{array}$ & $\begin{array}{c}\text { Asymp. Sig. } \\
\text { (2-tailed) }\end{array}$ & Keterangan \\
$\begin{array}{c}\text { Persamaan } \\
\text { Unstandardized } \\
\text { Residual }\end{array}$ & 0,554 & & Data \\
& & 0,919 & $\begin{array}{c}\text { Terdistribusi } \\
\text { Normal }\end{array}$ \\
\end{tabular}

Sumber: Data diolah, 2018

Hasil Pengujian Kolmogrov-Smirnov pada Tabel 4. menunjukkan bahwa nilai signifikansi untuk persamaan model regresi adalah $0,991(0,991>0,05)$. Hal ini menunjukkan bahwa persamaan regresi dalam model penelitian ini memiliki sebaran data yang normal.

Uji multikolinieritas digunakan untuk mengetahui apakah antara variabel bebas terjadi multikolinieritas atau tidak. Uji yang digunakan yaitu dengan 
melihat nilai VIF (Varian Inflation Factor) dan Tolerance pada proses regresi biasa, jika keduanya mendekati 1 atau besaran VIF kurang dari 10 maka model tidak terkena multikolinieritas. Berdasasrkan hasil pengujian multikolinearitas dapat diperoleh hasil sebagai berikut.

Tabel 5.

Hasil Uji Multikolinearitas

\begin{tabular}{|c|c|c|c|}
\hline Variabel & Tolerance & VIF & Keterangan \\
\hline Independensi (X1) & 0,348 & 2,871 & $\begin{array}{c}\text { Tidak terjadi } \\
\text { multikolinearitas }\end{array}$ \\
\hline Kompetensi (X2) & 0,404 & 2,475 & $\begin{array}{c}\text { Tidak terjadi } \\
\text { multikolinearitas }\end{array}$ \\
\hline Integritas (X3) & 0,356 & 2,807 & $\begin{array}{c}\text { Tidak terjadi } \\
\text { multikolinearitas }\end{array}$ \\
\hline Struktur Audit (X4) & 0,379 & 2,641 & $\begin{array}{c}\text { Tidak terjadi } \\
\text { multikolinearitas }\end{array}$ \\
\hline
\end{tabular}

Sumber: Data diolah, 2018

Hasil regresi pada Tabel 5. menunjukkan bahwa nilai tolerance pada masing-masing variabel lebih besar dari $10 \%(0,1)$, demikian pula dengan nilai VIF masing-masing variabel yang lebih kecil dari 10. Dengan demikian dapat disimpulkan antara variabel independensi (X1), kompetensi (X2), integritas (X3), dan struktur audit (X4) tidak terjadi multikolinearitas.

Uji Heteroskedastisitas bertujuan untuk menguji apakah dalam model terjadi ketidaksamaan varian atau residual satu pengamatan ke pengamatan lainnya. Jika tingkat signifikan lebih besar dari 0,05 maka terjadi heteroskedastisitas.

Tabel 6.

Hasil Uji Heteroskedastisitas

\begin{tabular}{|c|c|c|c|c|c|}
\hline \multirow{2}{*}{ Variabel } & \multicolumn{2}{|c|}{$\begin{array}{l}\text { Unstandardized } \\
\text { Coefficients }\end{array}$} & \multirow{2}{*}{$\begin{array}{c}\text { Standardized } \\
\text { Coefficients } \\
\text { Beta } \\
\end{array}$} & \multirow{2}{*}{ Sig. } & \multirow{2}{*}{ Keterangan } \\
\hline & B & $\begin{array}{l}\text { Std. } \\
\text { Error }\end{array}$ & & & \\
\hline (Constant) & 1,986 & 1,121 & & 0,082 & $\begin{array}{c}\text { Lulus Uji } \\
\text { Heteroskedastisitas }\end{array}$ \\
\hline $\begin{array}{l}\text { Independensi } \\
\text { (X1) }\end{array}$ & $-0,063$ & 0,042 & $-0,324$ & 0,136 & $\begin{array}{c}\text { Lulus Uji } \\
\text { Heteroskedastisitas }\end{array}$ \\
\hline $\begin{array}{l}\text { Kompetensi } \\
\text { (X2) }\end{array}$ & 0,031 & 0,037 & 0,164 & 0,413 & $\begin{array}{c}\text { Lulus Uji } \\
\text { Heteroskedastisitas }\end{array}$ \\
\hline
\end{tabular}




\begin{tabular}{cccccc}
$\begin{array}{c}\text { Integritas (X3) } \\
\text { Struktur Audit } \\
\text { (X4) }\end{array}$ & 0,034 & 0,027 & 0,272 & 0,204 & $\begin{array}{c}\text { Lulus Uji } \\
\text { Heteroskedastisitas } \\
\text { Lulus Uji }\end{array}$ \\
\hline Sumber: Data diolah, 2018 & $-0,233$ & 0,141 & $-0,340$ & 0,104 & Heteroskedastisitas \\
\hline
\end{tabular}

Tabel 6. menunjukkan bahwa seluruh variabel memiliki nilai signifikan lebih besar dari 0,05 sehingga model regresi pada penelitian ini tidak mengandung gejala heteroskedastisitas.

Sesuai dengan hasil perhitungan dengan menggunakan program SPSS for windows maka diperoleh hasil analisis regresi linear berganda. Dari Tabel 7. dapat disusun persamaan regresi linear berganda yaitu:

$Y=-3,597+0,163 X 1+0,170 X 3+0,429 X 3+0,081 X 3+\Sigma$

Tabel 7.

Hasil Analisis Regresi Linear Berganda

\begin{tabular}{|c|c|c|c|c|c|}
\hline \multirow[t]{2}{*}{ Variabel } & \multicolumn{2}{|c|}{$\begin{array}{c}\text { Unstandardized } \\
\text { Coefficients }\end{array}$} & \multirow{2}{*}{$\begin{array}{c}\begin{array}{c}\text { Standardized } \\
\text { Coefficients }\end{array} \\
\text { Beta }\end{array}$} & \multirow[t]{2}{*}{ Sig. } & \multirow{2}{*}{$\begin{array}{l}\text { Hasil Uji } \\
\text { Hipotesis }\end{array}$} \\
\hline & $\mathbf{B}$ & Std. Error & & & \\
\hline (Constant) & $-3,597$ & 1,814 & & 0,052 & \\
\hline $\begin{array}{l}\text { Independensi } \\
\text { (X1) }\end{array}$ & 0,163 & 0,068 & 0,141 & 0,020 & $\mathrm{H}_{1}$ Diterima \\
\hline $\begin{array}{l}\text { Kompetensi } \\
\text { (X2) }\end{array}$ & 0,170 & 0,060 & 0,154 & 0,007 & $\mathrm{H}_{2}$ Diterima \\
\hline Integritas (X3) & 0,429 & 0,043 & 0,577 & 0,000 & $\mathrm{H}_{3}$ Diterima \\
\hline $\begin{array}{l}\text { Struktur Audit } \\
\text { (X4) }\end{array}$ & 0,801 & 0,228 & 0,198 & 0,001 & $\mathrm{H}_{4}$ Diterima \\
\hline $\begin{array}{l}\text { Adjusted } \mathrm{R}_{\text {square }} \text { : } \\
\text { Sig. } \mathrm{F}_{\text {hitung }}\end{array}$ & & & & & \\
\hline
\end{tabular}

Nilai konstanta $(\alpha)$ menunjukkan nilai -3,597, maka audit tidak berkualitas tanpa adanya nilai independensi, kompetensi, integritas, dan struktur audit konstan. Nilai koefisien ( $\beta 1)$ sebesar 0,163 . Nilai koefisien yang positif menunjukkan bahwa apabila independensi meningkat satu satuan, maka kualitas audit akan meningkat sebesar 0,163 satuan. Nilai koefisien $(\beta 2)$ sebesar 0,170 . Nilai koefisien yang positif menunjukkan bahwa apabila kompetensi meningkat 
satu satuan, maka kualitas audit akan meningkat sebesar 0,170 satuan. Nilai koefisien ( $\beta 3$ ) sebesar 0,429. Nilai koefisien yang positif menunjukkan bahwa apabila integritas meningkat satu satuan, maka kualitas audit akan meningkat sebesar 0,429 satuan. Nilai koefisien ( $\beta 4)$ sebesar 0,081. Nilai koefisien yang positif menunjukkan bahwa apabila struktur audit meningkat satu satuan, maka kualitas audit akan meningkat sebesar 0,081 satuan.

Uji kelayakan model bertujuan untuk mengetahui apakah model regresi yang digunakan dalam penelitian ini layak atau tidak digunakan sebagai alat analisis untuk menguji pengaruh variabel bebas pada variabel terikatnya. Hasil uji kelayakan model dapat dilihat pada Tabel 8. yaitu:

Tabel 8.

Hasil Uji Kelayakan Model

\begin{tabular}{lrrrrr}
\hline \multicolumn{1}{c}{ Model } & \multicolumn{1}{c}{ Sum of } & df & Mean Square & F & Sig. \\
& Squares & & & & \\
\hline 1 Regression & 1606,085 & 4 & 401,521 & 194,4545 & $0,000^{\mathrm{a}}$ \\
Residual & 113,515 & 55 & 2,064 & & \\
Total & 1719,600 & 59 & & & \\
\hline Sumber: Data diolah, 2018 & & &
\end{tabular}

Berdasarkan Tabel 8. menunjukkan bahwa hasil uji kelayakan model diperoleh nilai F hitung sebesar 194,4545 dengan tingkat signifikansi sebesar 0,000. Karena signifikansi $\mathrm{F}$ hitung lebih kecil dari 0,05 maka dapat disimpulkan bahwa model regresi yang digunakan untuk mengetahui pengaruh kompetensi dan pengalaman auditor pada audit judgment layak (fit).

Berdasarkan Tabel 7. menunjukkan bahwa koefisien determinasi yaittu nilai adjusted $R^{2}$ adalah 0,929 atau $92,9 \%$. Hal ini berarti sebesar 92,9\% variabel independensi, kompetensi, integritas, dan struktur audit dapat menjelaskan variasi 
dari kualitas audit, sedangkan $17,1 \%$ sisanya dijelaskan oleh variabel lain di luar model.

Uji hipotesis bertujuan untuk mengetahui apakah masing-masing variabel independen mempunyai pengaruh secara signifikan pada variabel dependennya. Level of significant yang digunakan adalah 0,05 (5\%). Apabila probabilitas signifikansi lebih kecil dari 0,05 maka H0 ditolak dan H1 diterima. Berdasarkan Tabel 8. maka hasil pengujian secara parsial masing-masing variabel independen terhadap dependen dapat dijabarkan sebagi berikut.

Hipotesis pertama $\left(\mathrm{H}_{1}\right)$ yang menyatakan bahwa independensi berpengaruh positif terhadap kualitas audit aparat inspektorat dalam pengawasan keuangan daerah. Dari hasil uji statistik diperoleh nilai koefisien regresi variabel independensi adalah 0,163. Nilai ini signifikan pada tingkat signifikansi 0,05 dengan $p$ value 0,020 . Hasil tersebut didukung oleh nilai $\mathrm{t}_{\text {hitung }}=2,402>\mathrm{t}_{\text {tabel }}=-$ 1,513 yang menunjukkan bahwa independensi berpengaruh positif terhadap kualitas audit aparat inspektorat.

Penelitian ini sejalan dengan penelitian yang dilakukan oleh Alim, et.al (2007), dan I. A. Angge Septiari (2013) yang menyimpulkan bahwa independensi berpengaruh secara signifikan terhadap kualitas audit. Suatu proses audit tidak dibenarkan memihak kepada siapapun, karena apabila seorang auditor kehilangan sikap independensinya walaupun memiliki kompetensi yang tinggi, maka auditor tersebut tidak akan bisa untuk mempertahankan kebebasan pendapatnya.

Untuk menjaga tingkat independensi sangatlah tidak mudah agar tetap sesuai dengan jalur yang seharusnya. Kerjasama dengan klien yang terlalu lama 
bisa menimbulkan kerawanan atas independensi yang dimiliki auditor. Selain itu juga berbagai fasilitas yang disediakan oleh kliennya selama penugasan audit untuk auditor. Sehingga auditor akan berada pada posisi yang dilematis karena mungkin akan mudah dikendalikan oleh auditan.

Hasil penelitian ini tidak sejalan dengan penelitian yang dilakukan oleh Muh. Taufiq Efendy (2010) dan Achmad Badjuri (2012) yang menyatakan bahwa independensi tidak berpengaruh terhadap kualitas hasil pemeriksaan. Hal tersebut menunjukkan bahwa independensi auditor sektor publik tidak mempengaruhi kualitas hasil pemeriksaan yang dihasilkan. Aparat inspektorat masih terpengaruh dengan penentu kebijakan dan sering adanya mutasi antar satuan kerja perangkat daerah. Akibatnya, meskipun aparat acapkali mendapat fasilitas dari auditee, namun aparat tetap menganggap bahwa audit yang baik tetap harus dilaksanakan.

Hipotesis kedua $\left(\mathrm{H}_{2}\right)$ yang menyatakan bahwa kompetensi berpengaruh positif terhadap kualitas audit aparat inspektorat dalam pengawasan keuangan daerah. Dari hasil uji statistik diperoleh nilai koefisien regresi variabel kompetensi adalah 0,170 . Nilai ini signifikan pada tingkat signifikansi 0,05 dengan $p$ value 0,007. Hasil tersebut juga didukung oleh perhitungan nilai $t_{\text {hitung }}=2,828>t_{\text {tabel }}=$ 0,825 yang menunjukkan bahwa kompetensi berpengaruh positif terhadap kualitas audit aparat inspektorat dalam pengawasan keuangan daerah.

Hasil pengujian ini sejalan dengan hasil penelitian yang dilakukan oleh Alim, M.N., T. Hapsari, dan L. Purwanti (2007), Achmad Badjuri (2012) dan Muh. Taufiq Efendy (2010) yang menyatakan bahwa kompetensi berpengaruh signifikan terhadap kualitas audit. Untuk meningkatkan kualitas audit, seorang 
auditor sangat bergantung pada tingkat kompetensinya. Jika auditor memiliki kompetensi yang baik maka auditor akan dengan mudah melakukan tugas-tugas auditnya dan sebaliknya jika rendah maka dalam melaksanakan tugasnya, auditor akan mendapatkan kesulitan-kesulitan sehingga kualitas audit yang dihasilkan akan rendah pula.

Namun kompetensi yang ditinjau dari pengalaman auditor tidak berpengaruh signifikan terhadap kualitas. Hal tersebut membuktikan bahwa kompetensi auditor yang ditinjau dari pengalaman tidak berpengaruh terhadap kualitas auditnya. Hal tersebut terjadi karena pengalaman seorang auditor dalam melakukan audit sudah lama dan banyak, tanpa adanya pengetahuan yang dimiliki maka hasil audit tidak akan mencapai hasil yang maksimal.

Hipotesis ketiga $\left(\mathrm{H}_{3}\right)$ yang menyatakan bahwa independensi berpengaruh positif terhadap kualitas audit aparat inspektorat. Dari hasil uji statistik diperoleh nilai koefisien regresi variabel independensi adalah 0,429. Nilai ini signifikan pada tingkat signifikansi 0,05 dengan $p$ value 0,000 . Hasil tersebut didukung oleh nilai $t_{\text {hitung }}=9,935>t_{\text {tabel }}=1,285$ yang menunjukkan bahwa independensi berpengaruh positif terhadap kualitas audit aparat inspektorat.

Berdasarkan hasil uji statistik, maka diketahui bahwa integritas berpengaruh terhadap kualitas audit. Hasil penelitian ini sejalan dengan penelitian Carolita dan Rahardjo (2011) serta Arianti (2014) yang menunjukkan bahwa integritas auditor berpengaruh signifikan terhadap kualitas hasil pemeriksaan. Secara teori, penelitian ini sejalan dengan yang diungkapkan Mulyadi (2002:56) yang menyatakan bahwa integritas adalah suatu elemen karakter yang mendasari 
timbulnya pengakuan professional. Integritas merupakan kualitas yang mendasari kepercayaan publik dan merupakan patokan (benchmark) bagi anggota dalam menguji semua keputusan yang diambilnya. Integritas mengharuskan seorang anggota untuk, antara lain, bersikap jujur dan berterus terang tanpa harus mengorbankan rahasia penerima jasa, pelayanan dan kepercayaan publik tidak boleh dikalahkan oleh keuntungan pribadi.

Hasil tersebut dapat dipahami bahwa untuk meningkatkan kualitas audit seorang auditor sangat bergantung pada sikap integritasnya. Auditor yang memiliki integritas yang tinggi akan mengungkapkan hasil pemeriksaan secara jujur dan sesuai dengan kondisi yang ada di lapangan sehingga tidak terdapat salah saji material dalam penyajian laporan keuangan dan informasi yang terkandung dalam laporan keuangan dapat dipertanggungjawabkan dan dipercaya.

Hasil hipotesis keempat $\left(\mathrm{H}_{4}\right)$ ini menunjukkan nilai signifikansi t pada variabel struktur audit sebesar 0,001 yang berarti dibawah 0,05 dan $t_{\text {hitung }}=3,511$ $>\mathrm{t}_{\text {tabel }}=-1,655$ sehingga hipotesis ketiga diterima. Dari hasil uji statistik diperoleh nilai koefisien regresi variabel independensi adalah 0,801. Diterimanya hipotesis menunjukkan penelitian ini mendukung struktur audit secara signifikan berpengaruh positif terhadap kualitas audit. Hasil penelitian ini mendukung penelitian Fanani (2008) dan Eriani (2010) yang menunjukkan bahwa struktur audit berpengaruh positif terhadap kualitas audit.

Standar Pemeriksaan Keuangan Negara telah menjelaskan bagaimana langkah-langkah penentuan audit dan prosedur rangkaian logis dalam melaksanakan audit. Prosedur audit yang sistematis dan rinci membantu auditor 
dalam melaksanakan audit sehingga struktur audit terbukti membantu auditor inspektorat dalam meningkatkan kualitas auditnya.

Penelitian Bamber et al. (1989) menyatakan bahwa kantor akuntan publik yang menggunakan struktur audit akan meningkatkan kinerja auditor dan sebaliknya kantor akuntan publik yang menggunakan struktur audit memiliki potensi meningkatnya konflik peran dan ketidak jelasan peran yang dirasakan oleh staf auditnya. Stuart (2001) melakukan penelitian terhadap bagaimanakah pengaruh struktur audit terhadap kinerja auditor pada kompleksitas tugas tinggi dan rendah.

Hasil yang diperoleh menunjukkan struktur audit tidak berpengaruh secara langsung terhadap kinerja auditor. Kinerja auditor tergantung interaksi antara kompleksitas tugas dengan struktur audit yang digunakan dalam penerimaan audit. Untuk tugas analitis yang tidak terlalu kompleks, auditor dari perusahaan yang menggunakan struktur audit dan tidak menggunakan struktur audit menunjukkan kinerja yang sepadan. Sebaliknya, pada tugas yang relatif kompleks, maka auditor dari perusahaan yang tidak menggunakan struktur audit jauh berada di bawah perusahaan yang menggunakan struktur audit.

\section{SIMPULAN}

Berdasarkan pembahasan hasil penelitian di atas, dapat disimpulkan bahwa independensi, kompetensi, integritas, dan struktur audit berpengaruh positif signifikan terhadap kualitas audit di Kantor Inspektorat. Sedangkan saran yang dapat diberikan adalah Aparat Inspektorat sebaiknya lebih meningkatkan kualitas audit dan mampu menjalakan tugas dan tanggungjawab aparat pemerintah yang 
berkompeten. Guna meningkatkan kompetensi auditor dengan cara memberikan pendidikan pelatihan secara berkala kepada auditor dan meningkatkan fasilitasfasilitas. Diperlukannya komunikasi dan koordinasi yang baik dengan pimpinan dalam proses penyusunan program audit. Perlu menambah pelatihan dalam proses wawancara kepada obyek. Dan diperlukannya pemahaman dan menambah wawasan mengenai perbuatan yang tidak dibenarkan dalam proses audit. Serta seorang auditor internal juga tidak dibenarkan untuk memihak kepada pihak manapun serta mampu bersikap independen dan bebas dari tekanan pihak internal maupun eksternal. Bagi peneliti selanjutnya dapat memperluas area penelitian, menambah populasi penelitian maupun penambahan jumlah responden, dan menambahkan variabel independen lainnya.

\section{REFERENSI}

Achmad Badjuri. 2012. Analisis Faktor-Faktor yang Mempengaruhi Kualitas Hasil Pemeriksaan Audit Sektor Publik (Studi Empiris pada BPKP Perwakilan Jawa Tengah). Dinamika Akuntansi, Keuangan, dan Perbankan. Volume 1. Nomor 2.

Alim, M.N., T. Hapsari, dan L. Purwanti 2007. Pengaruh Kmpetensi dan Independensi terhadap Kualitas Audit dengan Etika Auditor sebagai Variabel Moderasi.Simposium Nasional Akuntansi X .Makassar

Bamber, E.M. and Snowball, D. (1988), "An experimental study of the effects of audit structure in uncertain task environments", The Accounting Review, Vol. 58 No. 3, pp. 490-504.

Carolita, K. Metha dan Rahardjo, N. Shiddiq. 2012. Jurnal. Pengaruh Pengalaman Kerja, Independensi Objektifitas, Integritas, Kompetensi, dan Komitmen Organisasi Hasil Audit. DIPONEGORO JOURNAL OF ACCOUNTING Volume 1, Nomor 2, Tahun 2012, Halaman 1-11. Semarang. 
Efendy, Muhammad Taufiq. (2010). "Pengaruh Kompetensi, Independensi, Dan Motivasi Terhadap Kualitas Audit Aparat Inspektorat Dalam Pengawasan Keuangan Daerah”. Tesis dipublikasikan UNDIP 2010.

Falah, Syaikhul. (2005). Pengaruh Budaya Etis Organisasi Dan Orientasi Etika Terhadap Sensitivitas Etika (Studi Empiris Tentang Pemeriksaan Internal Di Bawasda Pemda Papua)

Hall, Stuart. 1997. Representation Cultural Representations And Signifying Practice. The Open University. Sage Publication. Ltd.

Mabruri dan Jaka Winarna.2010.Analisis Faktor-Faktor yang Mempengaruhi Kualitas Audit di Lingkungan Pemerintah Daerah.Simposium Nasional Akuntansi 13. Purwokerto.

Mardiasmo. 2005. Akuntansi Sektor Publik Edisi 2. Penerbit Andi. Yogyakarta Mulyadi, 2002. Auditing, Buku Dua, Edisi Ke Enam, Salemba Empat, Jakarta

Pusdiklatwas BPKP. 2005. Auditing, Edisi ketiga, Modul Diklat Pembentukan Auditor Ahli.

Rai, Agung. 2008. Audit Kinerja Pada Sektor Publik. Penerbit Salemba Empat.

Septiari, I.A. Angge. 2013. "Pengaruh Kompetensi dan Independensi terhadap Kualitas Audit (Studi Empiris pada 5 Kantor Inspektorat Provinsi Bali)". http://ejournal.undiksha.ac.id/index.php/S1ak/article/download/357/308, diakses pada tanggal 22 Februari 2014 Pukul 7.56.

Sugiyono. (2013). Metode Penelitian Kombinasi (Mixed Methods). Bandung: Alfabeta.

Sukriah, dkk.(2009). Pengaruh Pengalaman Kerja, Independensi, Obyektifitas, Integritas dan Kompetensi terhadap Kualitas Hasil Pemeriksaan.Simposium Nasional Akuntansi 12 Palembang.

Sunarsip. 2001.Corporate Governance Audit:Paradigma Baru Profesi Akuntan dalam Mewujudkan Good Corporate Governance. Artikel Media Akuntansi, No.17, Th. VII, April-Mei 2001.

Sunarto. 2003. Auditing. Edisi Revisi Cetakan Pertama. Penerbit Panduan.Yogyakarta.

Tubbs, R.M. 1992. The Effect of Experience on Auditor's Organization and Amount of Knowledge. The Accounting Review, 67 (Oktober), 783-801 